\title{
Stock structure of black scabbardfish (Aphanopus carbo Lowe, 1839) in the southern northeast Atlantic
}

\author{
LEONEL SERRANO GORDO $^{1}$, IRINEU BAPTISTA ${ }^{2}$, LUCÍLIA CARVALHO ${ }^{3}$, \\ VALENTINA COSTA ${ }^{4}$, CRISTINA CRUZ ${ }^{5}$, JORGE C. EIRAS ${ }^{5}$, INÊS FARIAS ${ }^{6}$, \\ IVONE FIGUEIREDO ${ }^{6}$, HELENA LOURENÇO ${ }^{2}$, PEDRO BORDALO-MACHADO ${ }^{6}$, \\ ANA NEVES ${ }^{1}$, MARIA LEONOR NUNES ${ }^{2}$, SARA REIS ${ }^{7}$, MARIA JOÃO SANTOS ${ }^{5}$, \\ AURÉLIA SARAIVA ${ }^{5}$ and ANA RITA VIEIRA ${ }^{1}$
}

\footnotetext{
${ }^{1}$ Departamento de Biologia Animal and Centro de Oceanografia, Faculdade de Ciências da Universidade de Lisboa, Bloco C2, Campo Grande, 1749-016 Lisboa, Portugal. E-mail: 1sgordo@fc.ul.pt

${ }^{2}$ Unidade de Valorização dos Produtos da Pesca e da Aquicultura, IPIMAR, Av. Brasília, 1449-006 Lisboa, Portugal.

${ }^{3}$ Departamento de Estatística e Investigação Operacional, Faculdade de Ciências da Universidade de Lisboa, Bloco C6, Campo Grande, 1749-016 Lisboa, Portugal.

${ }^{4}$ Departamento de Oceanografia e Pescas, Universidade dos Açores 9901-862 Horta, Portugal.

${ }_{5}^{5}$ Departamento de Zoologia e Antropologia, Faculdade de Ciências, Universidade do Porto, Rua do Campo Alegre, S/N, Edifício FC4, 4169-007 Porto, Portugal and CIIMAR, Centro Interdisciplinar de Investigação Marinha e Ambiental, Universidade do Porto, Rua dos Bragas 289, 4050-123 Porto, Portugal.

${ }^{6}$ Unidade de Recursos Marinhos e Sustentabilidade, IPIMAR, Av. Brasília, 1449-006 Lisboa, Portugal.

${ }^{7}$ Direcção de Serviços de Investigação das Pescas, Estrada da Pontinha, 9004-562 Funchal, Portugal.
}

SUMMARY: Black scabbardfish stock structure is still unknown in European waters where, due to the scarcity of biological information, the ICES considers that there is a single stock unit. This study is the final outcome of a scientific project that applies a holistic approach to research on the population structure of the black scabbardfish and aims to define the most appropriate strategy for the conservation of this resource in southern NE Atlantic waters. The factors studied include life history parameters, otolith shape analysis, parasites, landings-and-effort data and contaminants. Sampling was conducted between 2005 and 2007 in three areas of the southern NE Atlantic: mainland Portugal, Madeira and the Azores. The mainland and the Azores have an established commercial fishery, whereas the Azores has only an exploratory fishery. The majority of results indicated the existence of different stocks of black scabbardfish in the study area. Of the 8 parameters, 6 were in agreement with separate stocks between the mainland and Madeira, 5 were in agreement with separate stocks between the mainland and the Azores, and 4 were in agreement with separate stocks between Madeira and the Azores.

Keywords: Aphanopus carbo, black scabbardfish, stock identity, holistic approach, Northeast Atlantic.

RESUMEN: Estructura DE STOCK DE SABLE NEgRo (APHANopUs CARBo LOWE, I839) EN EL SUR DEL AtLÁNTICO NORDESTE. - La estructura de la población de sable negro en las aguas europeas es todavía desconocida y, debido a la escasez de la información biológica disponible, ICES ha considerado una sola unidad de stock en la totalidad de dichas aguas. El proyecto que originó este estudio es un trabajo integrado para investigar la estructura poblacional de sable negro y pretende definir la estrategia más apropiada para la conservación de este recurso en aguas del sur del Atlántico nordeste. Para cumplir con el objetivo del proyecto se llevaron a cabo varios estudios: determinación de parámetros que definen el ciclo vital, análisis de forma del otolito, parásitos, datos de desembarques y esfuerzo pesquero, y contaminantes. El muestreo fue realizado entre 2005 y 2007 en tres áreas del sur del Atlántico nordeste: Portugal continental, aguas de Madeira y Azores. Las dos primeras áreas tienen una pesquería comercial establecida, mientras que en Azores existe una pesquería exploratoria. La mayoría de los resultados concluyeron la existencia de diferentes unidades poblacionales del sable negro en el área sur del Atlántico nordeste. Seis de los ocho parámetros confirman la separación entre los individuos del continente y Madeira, mientras que 5 parámetros corroboran la separación entre el continente y Azores. Solamente 4 técnicas corroboran la separación entre Madeira y Azores.

Palabras clave: Aphanopus carbo, sable negro, identidad de stock, aproximación holística, Atlántico nordeste. 


\section{INTRODUCTION}

There are several published stock concept definitions (Booke, 1981; Ihssen et al., 1981; Carvalho and Hauser, 1994), each one aiming to better characterise a homogeneous unit of fish: the fish stock. Each fish stock is identified on the basis of a number of distinctive characteristics that vary due to environmental and genetic factors. Phenotypic characteristics within stocks are associated with environmental characteristics, whereas phenotypic characteristics between stocks are associated with geographic region (Begg and Waldman, 1999). Some authors (e.g. Booke, 1981, 1999; Carvalho and Hauser, 1994) emphasise the importance of molecular techniques in stock identification issues while others (e.g. Cadrin and Friedland, 2005; Swain and Foote, 1999) have highlighted the importance of phenotypic variation due to the broad number of techniques that can be used to identify stocks (Begg et al., 1999a). However, these two approaches must be viewed as complementary.

The final application of the stock concept is to understand the stock structure of a species in order to properly assess and manage fish resources. It is therefore often the management needs that dictate the choice of stock identification techniques and the type of variation required to define stocks (Begg et al., 1999a). Genetic variation is useful for determining evolutionary differences between stocks, whereas phenotypic variation is more applicable to studying short-term environmentally-induced differences between stocks.

The stock identification techniques should cover multiple aspects of the biology and life characteristics of a fish species, as suggested by Pawson and Jennings (1996). Begg and Waldman (1999) suggest a holistic approach to stock identification because the integrative effect of this approach maximises the likelihood of correctly defining fish stocks. They define a holistic approach as "one that utilises multiple techniques for fish stock identification and can include, ideally, for more direct comparisons using a wide range of stock identification techniques on the same samples". According to the same authors, such an approach would enable a higher degree of confidence in a particular stock structure, compared with the one generated by a single procedure. This would be particularly important for situations in which different techniques provide different interpretations of stock affinities. In such cases, reliance on a single procedure could provide an inaccurate representation of the underlying stock structure of a species, which could have significant management implications in the utilisation and conservation of its stocks.

Although the importance of stock structure information for effective fisheries management is widely accepted, the number of case studies in which stock structure information is actually implemented in stock assessment and fisheries management is far from being optimal (Begg et al., 1999a); the case study on horse mackerel (Abaunza et al., 2008) is one of the examples of its broad application.

Many commercially important species are not subject to study before they began to be exploited and managers recognise that there is little option but to institute short-term reactive measures (Pawson and Jennings, 1996). This is mostly true for deepwater species and the black scabbardfish (Aphanopus carbo Lowe, 1839) in particular, since its stock structure is still unknown. In fact, little is known about its life cycle: the only documented areas of reproduction are around the Canary Islands (Pajuelo et al. 2008), NW Africa (Perera, 2008) and Madeira Island, where the species spawns mainly between October and December (Carvalho, 1988), but no eggs or larvae have ever been caught and juvenile fish are seldom caught.

The black scabbardfish is a trichiurid species with a wide distribution area, inhabiting the NE Atlantic from Iceland to the Madeira and Canary Islands (Mauchline and Gordon, 1984; Merrett et al., 1991; Pajuelo et al., 2008), the southern Indian Ocean (Piotrovskii, 1979) and the northwest Pacific (Clarke and Wagner, 1976). In the North Atlantic the genus Aphanopus has two species, A. carbo and A. intermedius Parin 1993. Both occur in a wide depth range (from $200 \mathrm{~m}$ to $1700 \mathrm{~m}$ for $A$. carbo and to $1350 \mathrm{~m}$ for A. intermedius) and have a wide distribution (Nakamura and Parin, 1993), with records in the northwest and east Atlantic and Pacific (only the northwest Pacific in the case of A. carbo). However, in the east Atlantic, A. intermedius has a southern distribution, occurring around the Canary Islands (and occasionally around Madeira) south to Angola, whereas A. carbo has a northern distribution, occurring from Iceland to the Canary Islands (Nakamura and Parin, 1993).

The eventual presence of A. intermedius in Portuguese waters has been an object of concern since the beginning of the study of black scabbardfish by Portuguese researchers in the 1990s. In fact, the 
first effort to test the presence of A. intermedius in Portuguese waters was made between 1997 and 2000 , but its occurrence was not confirmed in the waters of mainland Portugal, Madeira or the Azores. Recently the species was also found by Stefanni and Knutsen (2007) in a precisely located area of the Azores, south of Pico Island. These authors studied two mtDNA regions of black scabbardfish caught in several areas of the NE Atlantic (mainland Portugal, Madeira, the Seine and Sedlo seamounts, the mid-Atlantic Ridge, six Azores islands and 3 fishing banks close to the Azores) and concluded that two groups were present: one including all the individuals from Madeira, mainland Portugal and the Faraday seamount and one including all the individuals from Pico Island (Azores); the remaining areas had individuals in both groups. One possible explanation for the differences in the specimens from this second group put forward by Stefanni and Knutsen (2007) was that they belong to A. intermedius instead of $A$. carbo and therefore that the former species could also occur in the Azores archipelago. These two species are morphologically similar, but $A$. intermedius has 102-108 vertebrae and 40-44 dorsal fin spines, compared with 97-100 vertebrae and 38-40 dorsal fin spines in A. carbo (Nakamura and Parin, 1993).

In the NE Atlantic, the black scabbardfish is caught by trawlers off the northern NE Atlantic (France, Ireland), whereas in Portuguese waters it is caught with longline. Figure 1 shows the total landings (tonnes) reported in mainland Portugal, Madeira, the Azores and northern Europe (sub-areas II, IV, V, VI and VII combined) for the last 20 years. In mainland Portugal, an increasing trend was observed between 1988 and 1993, followed by a slight decrease until 2000, since when the landings have been stable around 2700 tonnes per year. In Madeira, the first decade was marked by an increasing trend toward a maximum of 4430 tonnes recorded in 1998, whereas in the second decade a slight decreasing trend can be observed, with the landings in 2007 attaining a value close to 2900 tonnes. In Portugal, the black scabbardfish is the most important deep-water fish exploited, and the landings have increased in the last decade to about 6000 tonnes: 3000 tonnes each in Madeira and mainland Portugal (Fig. 1). This increase in the exploitation has not been followed by an increase in scientific knowledge of its population dynamics. This deficiency has led to concern, already expressed by international and national

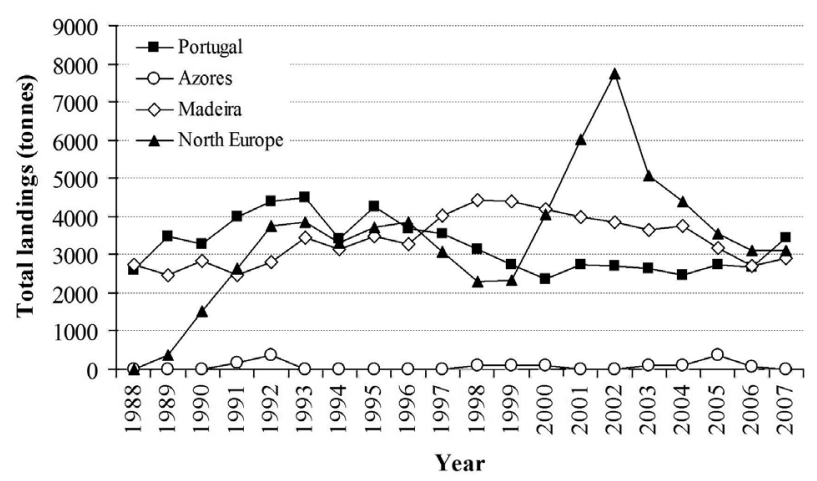

FIG. 1. - Total landings (tonnes) reported by mainland Portugal, Madeira, the Azores and northern Europe (sub-areas II, IV, V, VI and VII combined) for the last 20-year period. Sources for Madeira data, DREM (2008); for other data, ICES (2008).

authorities, about the sustainability of this resource under the actual unregulated exploitation.

In the Azores there is only an exploratory fishery, which explains the lower landings recorded in the whole time period. In northern Europe two main peaks can be seen: the first between 1992 and 1996 and the second in 2002. From this year onwards, a marked decrease can be observed until 2007 (Fig. 1).

Scientific references on this species are still few in number and mostly related to distribution, anatomy and general biology (Tucker, 1950; Zilanov and Shepel, 1975; Mauchline and Gordon, 1984; Carvalho, 1988; Morales-Nin and Sena-Carvalho, 1996; Gordon et al., 1996). Recent works have mainly focused on aspects of the reproductive biology (Bordalo-Machado et al., 2001; Figueiredo et al., 2003). Only two papers deal with stock structure (Quinta et al. 2004 and Stefanni and Knutsen, 2007). The authors of the first paper, using mtDNA, concluded that specimens living in Madeiran waters were different from those living on Hatton Bank (mid-Atlantic Ridge) and off the Portuguese mainland. Using the same technique, the authors of the second paper concluded that the individuals from the mid-Atlantic Ridge (the Faraday seamount), Madeira and the Portuguese mainland belonged to the same population unit.

The economic importance and the relatively high landings of black scabbardfish (with a mean value of over 7000 tonnes in European waters in the last decade (ICES, 2007) plus 3700 in Madeiran waters (DREM, 2008)) led researchers from several European countries to participate in an EU Project (Anon., 2000). This study provided the basis for the development and implementation of standard methodologies for biological sampling and a programme for the routine study of the black scabbardfish. 
However, at the end of the project, there was still a lack of knowledge on the stock structure. Thus, the ICES continued to consider a single species and a single stock for stock assessment purposes in the NE Atlantic.

In 2005, five Portuguese research institutions set up a scientific project to overcome the lack of knowledge on the species biology: APHACARBO (the black scabbardfish in Portuguese waters: measures of conservation and quality control). The main aim of this paper is to integrate the results of the methodologies followed in this project to improve the characterisation of the black scabbardfish population structure in the southern northeast Atlantic, providing valuable information for the correct identification of stocks and contributing, in the future, to the formulation of new management measures.

\section{MATERIALS AND METHODS}

In Portuguese waters, the black scabbardfish is the target species of an artisanal longline fishery that operates in mainland Portugal and Madeira (Fig. 2). In the Azores, there is no commercial fishery but only an exploratory fishery conducted by Madeiran vessels.

Black scabbardfish samples were obtained on a routine monthly basis at the landing port of Sesimbra (mainland Portugal) by IPIMAR (National Institute for Fisheries Research) and at the landing port of Funchal (Madeira) by DSIP (Regional Institute for Fisheries Research) to meet commitments in the EU data collection/PNAB (QCA III) project. In the Azores, sampling was obtained on an irregular basis. To study the species population structure, several techniques were used: reproductive parameters, age and growth, otolith shape, parasites, landings-perunit-of-effort and contaminant (mercury, cadmium and lead) level.

To meet the goals of the project and to study a possible temporal variation of certain characteristics (e.g. along the sexual cycle), samples were obtained in February/March June/July and October/November (the spawning period in Madeira waters) in the period from May 2005 to December 2007. Sample size varied according to the techniques (Table 1), but an effort was made to obtain a minimum number of individuals that was common to all techniques in order to facilitate the interpretation of the results. Nevertheless, due to the specificity of some techniques
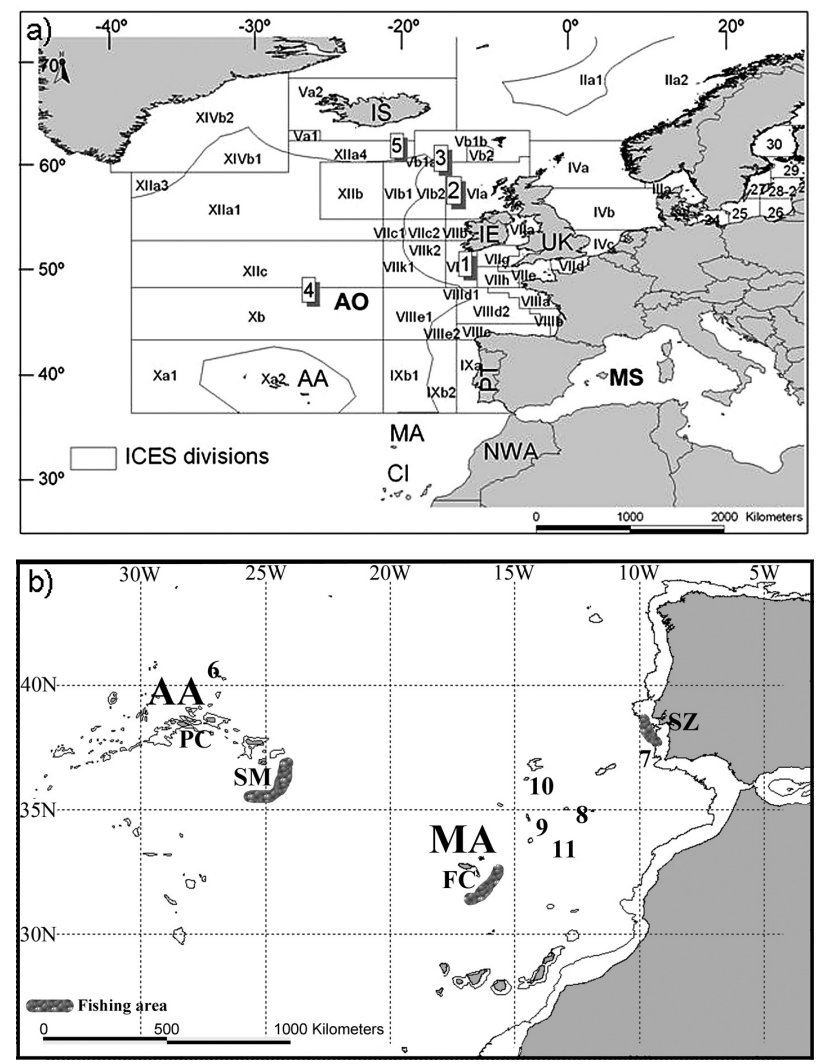

FIG. 2. - a) Map of the northeast Atlantic with the ICES divisions and b) the southern northeast Atlantic with the sampling locations of black scabbardfish and the $1000 \mathrm{~m}$ isobath. AA, Azores Archipelago; AO, Atlantic Ocean; CI, Canary Islands; FC, Funchal; IE, Ireland; IS, Iceland, MA, Madeira Archipelago; MS, Mediterranean Sea; NWA, Northwest Africa; PC, Pico Island; PT, mainland Portugal; SM, Santa Maria Island; SZ, Sesimbra (mainland Portugal); UK, United Kingdom; 1, Porcupine Seabight; 2, Rockall Trough; 3, Hatton Bank; 4, Faraday seamount; 5, Reykjanes Ridge; 6, Sedlo seamount; 7 , Gorringe seamount; 8 , Ampère seamount; 9 , Unicorn bank; 10, Lion seamount; 11, Seine seamount.

(e.g. life history) more individuals were obtained whenever it was necessary to achieve a balanced sampling design.

The possible presence of the two morphologically similar species (A. carbo and A. intermedius) in the distribution area required that sampling should be done with great care. Furthermore, the research team knew that some colleagues from Madeira and Azores had combined efforts to verify the occurrence of A. intermedius in the Portuguese waters and its occurrence has in fact been confirmed in landings of Pico Island (Azores) and Madeira but never in those of mainland Portugal (Sara Reis, pers. comm.). Therefore, in the present project, although the Azores specimens were mainly caught off Santa Maria (where the probability of presence of $A$. intermedius is smaller), they were morphologically analysed to be sure that only A. carbo were present. 
TABLE 1. - Number of specimens analysed in each technique. LPUE, landings per unit effort; $\mathrm{Hg}$, mercury; $\mathrm{Cd}$, cadmium; $\mathrm{Pb}$, lead.

\begin{tabular}{lcccccccc}
\hline & Age and growth & Otolith shape & Reproduction & Parasites & LPUE & Hg & $\mathrm{Cd}$ & $\mathrm{Pb}$ \\
\hline Mainland Portugal & 1075 & 488 & 949 & 116 & $(1)$ & 121 & 220 & 220 \\
Madeira & 436 & 488 & 2211 & 120 & (2) & 54 & 55 & 55 \\
Azores & 107 & 88 & 51 & 53 & & 135 & 39 & 39 \\
\hline
\end{tabular}

(1) logbooks for the period 1995-2007; (2) logbooks for the period 2005-2007

It was known that black scabbardfish abundance had decreased in Madeiran waters in the last few years and the fishermen had moved southwards (to Canary Islands waters where A. intermedius is more common) to obtain greater income. Therefore, the increase in the proportion of A. intermedius (which in some samples could reach $20 \%$, Sara Reis, pers. comm.) in the landings is due to the capture of both species south of Madeiran waters with larger vessels that can make longer trips. Therefore, to minimise the mixture effect, all samples used in the project were obtained from small vessels that operate near Madeira on daily trips. An effort was also made to determine whether specimens of $A$. intermedius were present in the samples and every individual morphologically analysed belonged to A. carbo.

For age and growth, since life history parameters vary temporally within stocks (Begg et al., 1999b), an extra sample was used from the two regions where a commercial fishery exists and for the period 1998-2004 (Vieira et al., 2009). For fecundity studies, an extra sampling was performed in September and October 2007 in order to obtain a number of females large enough to fulfil the task objective. In all samples, the majority of the individuals were adults but some juveniles were also obtained. The length distribution varied from $641 \mathrm{~mm}$ to $1330 \mathrm{~mm}$ in Sesimbra, from $1070 \mathrm{~mm}$ to $1481 \mathrm{~mm}$ in Funchal and from 945 to $1290 \mathrm{~mm}$ in the Azores. Nevertheless, in all techniques, a great effort was made to use the same length interval for the comparison of data from the different regions. In the laboratory, for each specimen the total length $(\mathrm{mm})$ and the total weight (g) were recorded. Sex was determined and the maturity stage was assigned according to Gordo et al. (2000). Finally, the otoliths were removed. Then, each technique followed its own methodology.

For the parasitological study, each specimen was submitted to a full autopsy to collect and identify the metazoan parasites (Cruz et al., 2009; Santos et $a l ., 2009)$. Then, the presence/absence, prevalence, mean intensity and mean abundance of each parasite species were compared among the three regions.
For the age and growth studies, the right otoliths were sectioned, mounted in a black polyester slide and observed in a binocular microscope. The annual periodicity of the growth increments was indirectly validated by the evolution over the year of the marginal increment in the otoliths. Once the annual nature of the growth increments had been validated, the age was determined as the number of translucent growth increments and age-length keys were obtained for sex, year and region. The distributions of length-atage were then compared for the same age range to determine whether: (i) there were any differences in the distributions of length-at-age between males and females; and (ii) there were any differences in the distributions of length-at-age between the three areas in comparison. Tukey's test with the Bonferroni adjustment was used for multiple comparisons between the three areas. Von Bertalanffy's growth model (von Bertalanffy, 1938) was also applied to back-calculation of mean length-at-age from mainland and Madeira data (the Azores samples were excluded since there were not enough data to perform this analysis) using FiSAT computer software (Gayanilo et al., 2005) and the growth parameters were compared using Hotelling's $\mathrm{T}^{2}$ test (Bernard, 1981) (Vieira et al., 2009).

Digital images of otoliths immersed in a 1:1 solution of glycerine-alcohol and positioned with the sulcus acusticus facing down and the rostrum to the left were used to obtain a two-dimensional projection of the distal side of the otolith (Farias et al., 2009). The contour shape of each otolith was extracted with the SHAPE program (Iwata and Ukai, 2002) following the principles of closed-form Fourier analysis (Kuhl and Giardina, 1982). This method decomposes the irregular shape of the contour into elliptic Fourier descriptors (EFDs). With SHAPE, the EFDs are automatically normalised (NEFDs) in relation to the first harmonic (represented by an offset circle and with almost no information on the contour shape) and subsequently they become invariant to size, rotation and starting point (Kuhl and Giardina, 1982; Iwata and Ukai, 2002). The effect of sampling location 
and sex on otolith contour shape was tested through multivariate analysis of variance (MANOVA) and discriminant analysis (DA) was applied to evaluate the success of assigning otoliths of a known sampling site to each geographical area.

Two sets of analyses were performed: (i) 200 otoliths per sex from mainland Portugal and from Madeira were randomly selected; and (ii) 44 otoliths per sex from mainland Portugal, Madeira and the Azores were then randomly selected. Only otoliths from specimens ranging from 1000 to $1030 \mathrm{~mm}$ total length were used.

For the reproductive studies (on sexual cycle, fecundity and the existence of skip spawning), the gonads were fixed and preserved in $10 \%$ buffered formaldehyde and processed histologically following standard criteria (Neves et al., 2009). The fecundity was estimated using both the gravimetric and stereological methods (Neves et al., 2009).

For the contaminant study (mercury, cadmium and lead), a piece of muscle, the gonad and liver were frozen for later analysis. The levels of cadmium and lead were determined by spectrophometry of flame atomic absorption (Costa et al., 2009), whereas the level of mercury was determined by cold vapour atomic absorption spectrophotometry (CV-AAS) (Costa et al., 2009). To evaluate the contribution of the factors region, sex and maturity stage, generalised linear models (GLMs) were adjusted to data for each combination of tissue and toxic metal. Multiple comparisons between the estimated marginal means of metal concentrations between different locations were performed using the least significant difference test (LSD test). LSD tests were used to evaluate the statistical significance of the differences in concentration between locations (Costa et al., 2009).

Standardised weekly estimates of landings-perunit-of-effort (LPUE) were obtained by a GLM. Nominal effort was calculated as number of hauls conducted per week. The best set of explanatory variables was selected based on Akaike's information criterion (Akaike, 1973; Hastie and Pregibon, 1992). Predictors of the GLM model included year and month effects, the two fishing regions and the group of vessel based on the clustering results. The model's goodness of fit was evaluated by graphic analysis of residuals (Bordalo-Machado et al., 2009). Using the LPUE temporal series of these two regions, a nonparametric statistical test was conducted to determine whether the series had originated by a unique and common stochastic process, and thus belonged to the same population. The non-parametric test was proposed by Caiado et al. (2008) for comparisons between two independent and stationary time series. For this test the series must have second-order stationarity and the normalised periodogram must be determined. In all statistical tests, a level of significance of $5 \%$ was applied.

Various multivariate and specific statistical tools were used to analyse the results within each technique. As in other studies using the same approach (e.g. Abaunza et al., 2008 for horse mackerel stock identification), the heterogeneity of the data used made it impossible to apply a single statistical tool to the common data matrix. Therefore, a critical comparative study for the results of each technique was applied in this paper.

\section{RESULTS}

The majority of the techniques used to identify the stock structure of black scabbardfish in the southern NE Atlantic revealed that a separation between black scabbardfish from two or three areas may exist (Table 2). Only the results on reproduction were inconclusive.

\section{Separation between black scabbardfish from the 3 areas (mainland, Azores and Madeira)}

Three methodologies (otolith shape, parasites and mercury level) support this separation. Otolith shape variation by elliptical Fourier analysis was undertaken in two separate studies due to the different number of individuals recorded in the Azores (88) in comparison with the other two regions (400) (Farias et al., 2009). In the first analysis, 200 individuals from mainland Portugal and Madeira and with a total length varying between 1000 and $1300 \mathrm{~mm}$ were randomly selected by sex and region and the outline of their otoliths was compared. The MANOVA adjusted to data from mainland Portugal and Madeira showed significant differences between areas and between sexes; the interaction term was not statistically significant. Since the effect of sex on the otoliths' contour shape was shown to be significant, the discriminant analysis (DA) was performed for each sex separately, including fish length as a descriptive variable. The DA showed high correct classifications (87.5-89\%) and low misclassification error $(0.12$ for each sex). 
TABLE 2. - Results of the different techniques regarding black scabbardfish stock differentiation. Y, differentiation present; ?, not conclusive. LPUE, landings per unit effort; $\mathrm{Hg}$, mercury; $\mathrm{Cd}$, cadmium; $\mathrm{Pb}$, lead.

\begin{tabular}{lcccccccc}
\hline & Age and growth & Otolith shape & Reproduction & Parasites & LPUE & $\mathrm{Hg}$ & $\mathrm{Cd}$ & $\mathrm{Pb}$ \\
\hline Mainland vs Madeira & $\mathrm{Y}$ & $\mathrm{Y}$ & $?$ & $\mathrm{Y}$ & $\mathrm{Y}$ & $\mathrm{Y}$ & $\mathrm{Y}$ & \\
Mainland vs Azores & & $\mathrm{Y}$ & $?$ & $\mathrm{Y}$ & & $\mathrm{Y}$ & $\mathrm{Y}$ & $\mathrm{Y}$ \\
Madeira vs Azores & & $\mathrm{Y}$ & $?$ & $\mathrm{Y}$ & & $\mathrm{Y}$ & & $\mathrm{Y}$ \\
\hline
\end{tabular}

In the second study, 44 otoliths, also obtained randomly among specimens with similar lengths, were also analysed by sex for the three regions. The effect of the area also proved to be significant when samples from the three regions were considered, but sexes were not significantly different and there was not interaction between the factors. To be comparable with the previous analysis, the DA was again performed for each sex separately. In this case, the correct classifications varied between 90.9 and $97.7 \%$ and the misclassification error was 0.08 for females and 0.04 for males. Otolith contour shape was hence shown to be a possible tool for differentiating between black scabbardfish stocks in the NE Atlantic.

Parasite analysis revealed that black scabbardfish from Madeira had the higher number of metazoan species (13), followed by those of the mainland (8) and the Azores (6) (Santos et al., 2009). Four species (Tentacularia coryphaenae, Nybelinia thyrsites, Heteronybelinia sp. and Campbelliella heteropoeciloacantha) were exclusive in Madeira specimens. Parasites can be used to discriminate black scabbardfish individuals from the three areas through a significant difference in: i) presence/ absence or ii) prevalence, intensity and abundance of certain parasite species. The most important species for this discrimination were the Monogenea Octoplectanocotyle aphanopi, larvae of Cestoda Tetraphyllidae, the Cestoda Trypanorhyncha Sphyriocephalus tergestinus, Tentacularia corypahenae, and Campbelliella heteropoeciloacantha, the Acanthocephala Bolbosoma vasculosum, and larvae of the Nematoda Anisakis sp. (Santos et al., 2009; Cruz et al., 2009).

The study of the mean level of mercury detected in three tissues (muscle, liver and gonads) showed the presence of significant differences $(\mathrm{p}<0.001)$ in all tissues and areas (Costa et al., 2009). Multiple comparisons using LSD test showed significant differences between the three tissues from the Azores and Madeira $(\mathrm{p}<0.001)$ and between Madeira and the mainland (gonad $(\mathrm{p}<0.01)$ and muscle and liver $(\mathrm{p}<0.001))$. Regarding the comparison between samples from the Azores and the mainland, significant differences were only obtained in muscle $(\mathrm{p}<0.01)$ (Costa et al., 2009).

\section{Separation between black scabbardfish from two areas}

\section{From the mainland and Madeira and from the mainland and the Azores}

One methodology (cadmium level) supports this separation. The level of cadmium (Cd) contamination was evaluated in three tissues: muscle, liver and gonads (Costa et al., 2009). The results obtained showed that the mean levels of $\mathrm{Cd}$ were significantly different in both the muscle $(p<0.05)$ and gonad $(p<0.01)$ in the specimens from Madeira and the mainland and in the muscle $(\mathrm{p}<0.001)$ and liver $(\mathrm{p}<0.001)$ between the Azores and the mainland (Costa et al., 2009).

From the Azores and Madeira and from the Azores and the mainland

One methodology (lead level) supports this separation. The level of lead $(\mathrm{Pb})$ contamination was evaluated in three tissues: muscle, liver and gonads (Costa et al., 2009). The mean levels of $\mathrm{Pb}$ were significantly different in the gonad $(\mathrm{p}<0.001)$ and liver $(\mathrm{p}<0.05)$ in the specimens from Madeira and Azores. The $\mathrm{Pb}$ level was also significantly different in the gonad $(\mathrm{p}<0.001)$, muscle $(\mathrm{p}<0.001)$ and liver $(p<0.05)$ between the specimens from the Azores and the mainland.

\section{From Madeira and the mainland}

Two methodologies (age and growth and LPUE analysis) support this separation, although the latter based on a conditional hypothesis drawn from LPUE analysis. Regarding age and growth, in both females and males significant differences among the three 
regions $(p<0.001)$ were found in the comparison of the mean length per age group (for the common age groups only) (Vieira et al., 2009). Turkey's test with the Bonferroni adjustment showed significant differences $(p=0.0029)$ in females only between Madeira and the mainland, whereas in males it showed significant differences both between the mainland and Madeira $(\mathrm{p}<0.001)$ and between the mainland and the Azores $(\mathrm{p}=0.0387)$. Statistical differences were also obtained in the comparison of the growth parameters for females $\left(\mathrm{T}^{2}=18.84\right.$; $\left.\mathrm{T}_{0}^{2}=11.97 ; \mathrm{T}^{2}>\mathrm{T}_{0}^{2}\right)$ and for males $\left(\mathrm{T}^{2}=44.38\right.$; $\left.\mathrm{T}_{0}^{2}=10.41 ; \mathrm{T}^{2}>\mathrm{T}_{0}^{2}\right)$ between Madeira and the mainland (Vieira et al., 2009).

The results of the comparison of two LPUE series, one from mainland Portugal and one from Madeira, suggests the existence of two different populations being exploited (Bordalo-Machado et al., 2009). However, if a scenario of horizontal migrations to spawning grounds in the NE Atlantic is envisaged (Figueiredo et al., 2003), one cannot exclude the hypothesis that the differences observed in the stochastic processes of the two regions are due to a temporal gap of the species life cycle. Assuming this last hypothesis, the LPUE time series were restructured (Bordalo-Machado et al., 2009) and compared again using the same non-parametric test. The new statistic test value obtained indicated a common stochastic process for the two series. This result is in agreement with the existence of a common exploited stock for individuals of both regions.

\section{Non-conclusive methodologies}

In this category, only the reproductive studies are included. The sexual cycle, fecundity and presence of skip spawning were investigated. Regarding the sexual cycle, a major difference was found between the specimens where a target commercial fishery occurs: the mainland and Madeira. In Madeiran waters, specimens in all maturity stages can be found, whereas in mainland waters the great majority of the specimens are in resting condition or at the beginning of development (Neves et al., 2009). In the Azores, due to a very irregular and exploratory fishery, no information on the sexual cycle could be obtained. The analysis of fecundity and the presence of skip spawning were only investigated in the only region where spawning is known to occur (Madeira), so no comparison between regions could be made regarding these issues.

\section{DISCUSSION}

The majority of the techniques used in the present study showed the existence of different black scabbardfish population units in the three areas studied, or at least between two of them: mostly mainland Portugal and Madeira. This was the case of life-history parameters (age and growth studies), otolith shape analysis, parasites and contaminants. Differences in life history parameters are taken as evidence that populations of fish are geographically and/or reproductively isolated (although mixing can occur seasonally) and are therefore discrete units for management purposes (Ihssen et al., 1981). Life history parameters usually include the study of age and growth, reproductive strategies, mortality estimates and distribution-a set of parameters that provide fundamental biological information and that are routinely collected for management purposes in most fisheries institutes (Begg et al., 1999b), at relatively low expense. In the present study, only age and growth and reproductive strategies were analysed.

Age and growth studies were analysed using four time-frame series in mainland Portugal and two time-frame series in Madeira. Begg et al. (1999b) consider that the use of a longer time period is necessary to ensure some stability in the interpretation of the results of life-history parameters regarding the stock structure, since life-history parameters may vary temporally within stocks. In fact, according to the same authors, the use of a single time frame to interpret any life history parameter may be very misleading. The results for age and growth indicated the presence of significant differences between the mean length at age and von Bertalanffy growth parameters of the individuals living in Madeiran and mainland waters, suggesting the presence of different stocks.

The reproductive strategies were the other life parameter studied in this project. This normally involves studying numerous parameters, including timing, duration and location of spawning; median or mean age/length at maturity; egg size and fecundity (Begg, 2005). However, in the analysed area only the individuals caught off Madeira reached maturity. In the Azores, because the fishery is only exploratory, very few individuals were sampled and no conclusion could be achieved regarding the presence of mature individuals. In waters of mainland Portugal, when females reach the beginning of the development stage, all individuals begin to suffer a generalised atresia in their oocytes (Neves et al., 
2009). Two possible events (or a combination of the two) may sustain the absence of reproductive specimens in mainland waters. The first one may be due to the stop of gametogenesis with the re-absorption of all vitellogenic oocytes via follicular atresia, which could be related to a continuous poorly nutritional condition. However, the Fulton condition factor does not totally support this hypothesis (Neves et al., 2009). The second possibility may be a migration to other areas to spawn. One could speculate that specimens that occur off mainland Portugal could migrate to Madeiran waters (the known spawning area) to spawn, but the abundance would be expected to increase in Madeiran waters during the spawning period (the last quarter of the year), which does not happen (Reis et al., 2008). Until very recently, only Madeiran waters were known to be a spawning area, but during the last year mature females were captured in two other areas: the Canary Islands $(\mathrm{Pa}-$ juelo et al., 2008) and the northwest coast of Africa (Perera, 2008). Therefore, it is possible that a migration may occur not to Madeiran waters but to one of the recently known areas near the African coast. The results obtained for reproductive strategies were thus not conclusive regarding the black scabbardfish stock structure.

Morphometry studies and otolith shape analysis in particular are frequently used in stock structure studies (Bird et al., 1986; Friedland and Reddin, 1994; Stransky et al., 2008) because they are speciesspecific (Tuset et al., 2008) and hardly vary with growth (Campana and Casselman, 1993). In fact, according to Ponton (2006) otolith shape analysis gives better results than other morphometrics traits because otoliths are not affected by short-term variations in fish physiological condition or by standard tissue-preservation techniques, and their appearance and shape often vary geographically. However, the extent to which otolith shape differences is genetically or environmentally induced is not clear (Cadrin and Friedland, 2005). In fact, whereas Lagler et al. (1977) consider the pattern of phenotypic expression to be similar to that of other calcified structures, Friedland and Reddin (1994) suggest that the greater influence on otolith shape may be genetic.

Due to different sampling sizes obtained in the three regions, two separate analyses were made to study otolith shape: the first one between individuals from mainland Portugal and Madeira and the second one between individuals from the three areas (Farias et al., 2009). Both results pointed to the presence of significant differences between the individuals living in the areas and therefore may suggest the presence of different stocks. Furthermore, the classification success was high for both analyses, supporting the results of a clear separation between the individuals from different areas. Nonetheless, special care should be taken when taking conclusions from the second analysis because the number of otoliths used (44 per region and sex) was very small (Farias et al., 2009).

According to MacKenzie and Abaunza (2005), the basic principle underlying the use of parasites as tags in fish population studies is that fish can become infected with a parasite only when they come within the endemic area of that parasite, the endemic area being that geographic region in which conditions are suitable for the transmission of the parasite; if infected fish are found outside the endemic area, one can infer that these fish had been within that area in their past history. The same authors suggest that the following criteria should also be taken into consideration in selecting parasites for stock identification studies: a) the persistency in the host for a long period of time; $b$ ) the presence of single-host life cycles; c) the constancy of the level of infection from year to year; d) the ease of parasite detection and identification; and e) the avoidance of very pathogenic parasites. Finally, the levels of infection in terms of prevalence, mean intensity, and/or abundance should be evaluated. In the study of black scabbardfish parasitological fauna, all the abovementioned criteria were taken into consideration and levels of infection were estimated. All parasites that occurred in specimens from mainland Portugal and the Azores also occurred in those of Madeira (the region with the highest specific richness), which also had 4 exclusive parasite species: Tentacularia coryphaenae, Nybelinia thyrsites, Heteronybelinia sp. and Campbelliella heteropoeciloacantha (Santos et al., 2009). The results of the parasitological descriptors (prevalence, intensity and abundance) associated with the significant differences in the presence/absence of certain parasite species made it possible to discriminate between black scabbardfish specimens from the three regions.

Contaminants may also be very important in the identification of the stock structure since they may provide information on the specimens' life history and movements. In fact, individuals that spend part of their life history in chemical contaminated waters may absorb or ingest these chemicals that will remain in the body tissues during the subsequent 
years (Pawson and Jennings, 1996). Mercury (Hg), cadmium $(\mathrm{Cd})$ and lead $(\mathrm{Pb})$ are among the most toxic contaminants in terms of public health and are commonly monitored in commercially important fish species. In the present work, the levels of both lead and cadmium were lower than the limits established by the European Union $(0.30$ and $0.05 \mathrm{mg} / \mathrm{kg}$, respectively) for human consumption and similar to the values reported by Mormede and Davies (2001) and Afonso et al. (2007) for specimens caught in the Rockall Trough and off the Azores and Madeira. Therefore, in terms of public health, there are no toxicological implications for human consumption. However, although the lead values obtained in the three regions were lower than $0.30 \mathrm{mg} / \mathrm{kg}$, there were significant differences between the levels found in all tissues analysed (muscle, liver and gonads) in the individuals caught in Madeiran and Azorean waters. The cadmium levels found in both muscle and gonads were significantly different in the individuals caught off mainland Portugal and those caught off Madeira and the Azores. Mercury is also an extremely toxic element without any known biological function for living organisms. The mean levels detected in the muscle of black scabbardfish from both mainland Portugal and Azorean waters were lower than the limits established by the European Union $(1.0 \mathrm{mg} /$ $\mathrm{kg}$ ) for human consumption. However, in Madeiran specimens, the muscle showed mean values higher than $1.0 \mathrm{mg} / \mathrm{kg}$, a situation already described by Bebiano et al. (2007), especially for specimens larger than $100 \mathrm{~cm}$. Comparing the $\mathrm{Hg}$ levels present in the three tissues analysed, significant differences were found in every tissue between specimens from mainland Portugal, Madeiran and Azorean waters. Therefore, all elements allowed the discrimination between black scabbardfish specimens from the three regions.

We also analysed fishery data, namely the catch per unit effort (CPUE) of the commercial fleet targeting black scabbardfish in mainland Portugal and Madeira, in order to understand the temporal evolution of this resource (Bordalo-Machado et al., 2009). Since the longline fishery has a much reduced bycatch, it was assumed that the amount of captures is practically equal to the amount of landings, so the landings per unit effort (LPUE) were analysed in both areas.

Regarding the identification of population units, the results of the comparison of the two LPUE series after the effort standardisation has been achieved suggest the possibility that two different populations are being exploited. However, although the results indicate the existence of divergences between the stochastic processes, we can also accept the hypothesis that these differences are a consequence of a time lag between the series, as a result of a species migration. Considering a 12 -week lag between the two processes, the 2 time series may have been originated by the same stochastic process. Therefore, only a comparative study using a broader time period (above 10 years, which is close to the maximum longevity estimated for the species (Morales-Nin et $a l .$, 2002)) can clarify this issue and help to understand the population structure in mainland Portugal and Madeiran waters.

Other techniques commonly used in identifying the stock structure were not applied because they could not be used (tagging, eggs and larvae) or because of financial constraints (otolith elemental analysis, genetics). Although tagging is a very interesting (and expensive) technique for studying migration and stock structure, it is still not possible to perform in deep-water species caught with longliners, although some interesting and promising experiences have already been carried out for trawl (Jacobsen and Hansen, 2005).

Eggs and larvae frequently provide information relevant to stock identification, because stock integrity generally depends upon spawning fish from different stocks being separated in space or time (Pawson and Jennings, 1996). Therefore, greater larval dispersal leads to more mixing of early life stages among spawning locations, which results in less stock structure (Hare, 2005). Unfortunately, no data on eggs and larvae have been recorded for black scabbardfish in Madeiran waters or during the few exploratory surveys carried out by the National Institute for Fisheries Research in the 1980s (Anon., 1982). Nursery areas (easily identified because they are often characterised by high densities of juveniles) have likewise never been found. In fact, the few small fish caught by fishermen are 2-year-old specimens with a total length of around $60 \mathrm{~cm}$.

The basis for otolith elemental analysis is that otoliths are permanent records of the influence of endogenous and exogenous factors on their calciumprotein matrices (Begg et al., 1999a). Because water bodies often differ in the concentrations of trace elements, stocks may often be distinguished by the chemical signatures retained in otoliths (Begg and Waldman, 1999). It is also assumed that otoliths are 
metabolically inert, so at any element deposited during growth of the otolith is fixed (Campana and Neilson, 1985). In a previous study on elemental analysis of black scabbardfish otoliths at six locations in the Northeast Atlantic to analyse the species stock structure, Swan et al. (2002) reported that the results were inconclusive. In fact, the results of the discriminant analysis showed that there were only small differences between the overall chemical signatures of the otoliths from the study areas, which are consistent with the single stock hypothesis. However, the authors found that some elements contributed to a better differentiation pattern of otoliths and, in this case, $\mathrm{Sr}$ and $\mathrm{Mg}$ were the elements that most contributed for discriminating between sampling locations: $\mathrm{Mg}$ concentrations were higher in the northern samples while $\mathrm{Sr}$ concentrations were higher in mainland Portugal and Madeiran samples.

Molecular genetic markers and quantitative phenotypic characters have both advantages and disadvantages for delineating fish stocks (Swain et al., 2005) and the best option is to use them in a holistic approach (Begg and Waldman, 1999). However, due to the reasons explained above, we followed a phenotypic approach to identify the black scabbardfish stock structure. We believe this is a valid option in the circumstances and, as Swain and Foote (1999) have argued, "the 'stocks' delimited by phenotypic differences may be the appropriate units for fisheries management even if this phenotypic divergence is not reflected by genetic differentiation". It must be taken into account that the lack of genetic differentiation does not prove that different stocks do not exist. Mixing percentages as low as $1 \%$ may give rise to a genetic homogeneity between the samples analysed (Ward, 2000). The sampling was also a major concern to avoid temporal variation. Therefore, a synchronous sampling during the spawning period was made in the areas where a commercial exploitation existed to assure that the putative stocks were homogenous and optimally separated (Ihssen et al., 1981).

Genetics is essential to stock identification studies because it considers fixed genotypic differences between individuals and stocks (Pawson and Jennings, 1996). Several genetic techniques (allozyme, mitochondrial DNA, microsatellite DNA, SSCP) have been used in stock identification in both pelagic (Cimmaruta et al., 2008; Comesaña et al., 2008; Kasapidis and Magoulas, 2008) and demersal (Roldan et $a l ., 1998)$ species. The results have not always been conclusive, showing, for example, low levels of ge- netic differentiation in horse mackerel (Abaunza $e t$ al., 2008) and a high level of differentiation in hake (Cimmaruta et al., 2005). Regarding black scabbardfish, two papers using the same approach (mt DNA) reached different results: one (Quinta et al., 2004) considered that Madeira and Portugal mainland specimens should belong to different populations while the other (Stefanni and Knutsen, 2007) considered that they should be included in the same stock unit.

The information from the multiple technique approach followed in this study will enable a higher degree of confidence in the stock structure in comparison with one generated by a single procedure. Due to finite resources, Begg and Waldman (1999) suggest that perhaps the most important management question concerning stock identification is how to make the proper choice from the techniques that are available. According to Begg et al. (1999a), this choice must balance costs, sampling needs, repeatability and likelihood of detecting multiple stocks, and the techniques used should be chosen to fit the particular context and management objectives of the study.

The results of this study support the existence of different Aphanopus carbo stocks units in the southern Northeast Atlantic. However, due to the use of exclusive quantitative phenotypic parameters, the default management scenario should be to use a precautionary approach (e.g. to consider the three areas as separate stocks) in order to ensure resource sustainability and maintenance of genetic biodiversity (Begg and Waldman, 1999). It is therefore recommended that genetic techniques be used in the near future to complement the above-mentioned studies and the described stock structure. Furthermore, this first attempt to examine the stock structure in the southern European region should be complemented by another study in the northern European areas to finally comprehend the black scabbardfish stock structure in the NE Atlantic.

\section{ACKNOWLEDGEMENTS}

The authors would like to thank Dr. Steve Cadrin, Dr. Francesc Maynou and two anonymous referees for their comments, which greatly improved the manuscript. This study was partially supported by the Fundação para a Ciência e Tecnologia (project POCTI/CVT/46851/2002). 


\section{REFERENCES}

Abaunza, P., A.G. Murta, N. Campbell, R. Cimmaruta, A.S. Comesaña, G. Dahle, M.T. García Santamaría, L.S. Gordo, S.A. Iversen, K. MacKenzie, A. Magoulas, S. Mattiucci, J. Molloy, G. Nascetti, A.L. Pinto, R. Quinta, P. Ramos, A. Sanjuan, A.T. Santos, C. Stransky and C. Zimmermann. - 2008. Stock identify of horse mackerel (Trachurus trachurus) in the Northeast Atlantic and Mediterranean Sea: Integrating the results from different stock identification approaches. Fish. Res., 89: 196-209.

Afonso, C., H.M. Lourenço, A. Dias, M.L. Nunes and C. Castro. 2007. Contaminant metals in black scabbard fish (Apahnopus carbo) caught off Madeira and the Azores. Food Chem., 101: 120-125.

Akaike, H. - 1973. Information theory and an extension of the maximum likelihood principle. In: B. N. Petrov and F. Csaki (eds.), Proceedings of the 2nd International Symposium on Information Theory, pp. 268-281. Budapest: Publishing House of the Hungarian Academy of Sciences.

Anon. - 1982. Programa de apoio às pescas na Madeira II. Cruzeiros de reconhecimento de pesca e oceanografia 020170680 020241180. Relatórios INIP, Lisboa, 11: 220 p.

Anon. - 2000. Environment and biology of deep-water species Aphanopus carbo in the NE Atlantic: basis for its management (BASBLACK). Final Consolidated Report of the European Commission DGXIV Study Contract 97/0084, 94p.

Bebiano, M.J., C. Santos, J. Canário, N. Gouveia, D. Sena-Carvalho and C. Vale. -2007 . $\mathrm{Hg}$ and metallothionein-like proteins in the black scabbardfish Aphanopus carbo. Food Chem. Toxicol., 45: 1443-1452.

Begg, G.A. - 2005. Life history parameters. In: S.X. Cadrin, K.D. Friedland and J.R. Waldman (eds.), Stock identification methods: applications in fisheries science, pp 119-150. Elsevier Academic Press, MA, USA.

Begg, G.A. and J.R. Waldman. - 1999. An holistic approach to fish stock identification. Fish. Res., 43: 35-44.

Begg, G.A., K.D. Friedland and J.B. Pearce. - 1999a. Stock identification and its role in stock assessment and fisheries management: an overview. Fish. Res., 43: 1-8.

Begg, G.A., J.A. Hare and D.D. Sheehan. - 1999b. The role of life history parameters as indicators of stock structure. Fish. Res., 43: 141-163.

Bernard, D.R. - 1981. Multivariate analysis as a means of comparing growth in fish. Can. J. Fish. Aquat. Sci., 38: 233-236.

Bird, J.L., D.T. Eppler and D.M. Checkley. - 1986. Comparisons of herring otoliths using Fourier-series shape-analysis. Can. J. Fish. Aquat. Sci., 43: 1228-1234.

Booke, H.E. - 1981. The conundrum of the stock concept - are nature and nurture definable in fishery science? Can. J. Fish. Aquat. Sci., 38: 1479-1480.

Booke, H.E. - 1999. The stock concept revisited: perspectives on its history in fisheries. Fish. Res., 43: 9-11.

Bordalo-Machado, P., I. Figueiredo, S. Reis , D. Sena-Carvalho, T. Blasdale, A. Newton, L.S. Gordo. - 2001. New findings on the reproductive biology of the black scabbardfish (Aphanopus carbo Lowe, 1839) in the NE Atlantic. NAFO SCR Doc. 01/89, $1-12$.

Bordalo-Machado, P., A.C. Fernandes, I. Figueiredo, O. Moura, S. Reis, G. Pestana and L.S. Gordo. - 2009. The black scabbardfish (Aphanopus carbo Lowe, 1839) fisheries from the Portuguese EEZ. Sci. Mar., 73S2: 63-76.

Cadrin, S.X. and K.D. Friedland. - 2005. Morphometric outlines. In: S.X. Cadrin, K.D. Friedland and J.R. Waldman (eds.), Stock identification methods: applications in fisheries science, pp. 173-183. Elsevier Academic Press, MA, USA.

Caiado, J., N. Crato and D. Peña. - 2008. Comparison of time series with unequal length. Munich Personal RePEc Archive, No. 6605 , p. 18.

Campana, S.E and J.D. Neilson. - 1985. Microstructure of fish otoliths. Can. J. Fish. Aquat. Sci., 42: 1014-1032.

Campana, S.E. and J.M. Casselman. - 1993: Stock discrimination using otolith shape analysis. Can. J. Fish. Aquat. Sci., 50: 10621083.

Carvalho, D. 1988. Relatório final do estudo efectuado sobre o Peixe-Espada Preto (Aphanopus carbo, Lowe, 1839) capturado na ZEE da Madeira. EC Report. DG XIV/CE Doc. No.
XIV/B/1-1987, $177 \mathrm{pp}$.

Carvalho, J.R. and L. Hauser. -1994. Molecular genetics and the stock concept in fisheries. Res. Fish Biol. Fish., 4: 326-350.

Cimmaruta, R., P. Bondanelli and G. Nascetti. - 2005. Genetic structure and environmental heterogeneity in the European hake (Merluccius merluccius). Mol. Ecol., 14: 2577-2591.

Cimmaruta, R., P. Bondanelli, A. Ruggi and G. Nascetti. - 2008. Genetic structure and temporal stability in the horse mackerel (Trachurus trachurus). Fish. Res., 89: 114-121.

Clarke, T.A. and P. J.Wagner. - 1976. Vertical distribution and other aspects of the ecology of certain mesopelagic fishes taken near Hawaii. Fish. Bull., U.S., 74: 635-645.

Comesaña A.S., Martínez-Areal, M.T. and A. Sanjuan. - 2008. Genetic variation in the mitochondrial DNA control region among horse mackerel (Trachurus trachurus) from the Atlantic and Mediterranean areas. Fish. Res., 89: 122-131.

Costa, V., H. M. Lourenço, I. Figueiredo, L. Carvalho, H. Lopes, I. Farias, L. Pires, C. Afonso, A. R. Vieira, M. L. Nunes and L. S. Gordo. - 2009. Mercury cadmium and lead in black scabbardfish, Aphanopus carbo Lowe, 1839, from mainland Portugal, Azores and Madeira Archipelagos. Sci. Mar., 73S2: 77-88.

Cruz, C., A. Saraiva, M.J. Santos, J.C. Eiras, C. Ventura, J. P. Soares and M. Hermida. - 2009. Anisakis (Nematoda: Anisakidae) infestation in Aphanopus carbo (Osteichthyes: Trichiuridae) from Portuguese waters. Sci. Mar., 73S2: 115-120.

Direcção Regional de Estatística da Madeira (DREM). - 2008. Série Retrospectiva. Estatística da Agricultura e Pescas (1976-2007). Secretaria Regional do Plano e Finanças, Região Autónoma da Madeira, 25pp.

Farias, I., A.R. Vieira, L.S. Gordo and I. Figueiredo. - 2009. Otolith shape analysis as a tool for population discrimination of black scabbardfish (Aphanopus carbo Lowe, 1839) in Portuguese waters. Sci. Mar., 73S2: 47-53.

Figueiredo, I., P. Bordalo-Machado, S. Reis, D. Sena-Carvalho, T. Blasdale, A. Newton and L.S. Gordo. - 2003. Observations on the reproductive cycle of the black scabbardfish (Aphanopus carbo Lowe, 1839) in the NE Atlantic. ICES J. Mar. Sci., 60: 774-779.

Friedland, K.D. and D.G. Reddin. - 1994. Use of otolith morphology in stock discriminations of Atlantic salmon (Salmo salar). Can. J. Fish. Aquat. Sci. 51: 91-98.

Gayanilo, F.C. Jr., P. Sparre and D. Pauly. - 2005. The FAOICLARM stock-assessment tools II (FiSAT II). Revised version. User's guide. FAO Computerised Information Series (Fisheries) 8, FAO, Rome, 168 pp.

Gordo, L.S., D.S. Carvalho, I. Figueiredo, S. Reis, P.B. Machado, A. Newton, and J. Gordon. - 2000. Escala de maturação sexual do peixe-espada preto: uma abordagem macro e microscópica. The sexual maturity scale of black scabbardfish: a macro- and microscopic approach. Celta Editora, Oeiras.

Gordon, J.D.M, N.R. Merrett, O.A Bergstad and S.C. Swan. - 1996. A comparison of the deep-water demersal fish assemblages of the Rockall Trough and Porcupine Seabight, eastern North Atlantic: continental slope to rise. J. Fish Biol., 49 (Suppl. A): 217-238.

Hare, J.A. - 2005. The use of early life stages in stock identification studies. In: S.X. Cadrin, K.D. Friedland and J.R. Waldman (eds.), Stock identification methods: applications in fisheries science, pp. 89-117. Elsevier Academic Press, MA, USA.

Hastie T.J. and D. Pregibon. - 1992. Generalized linear models. In: J.M. Chambers and T.J. Hastie (eds.), Chapter 6 of Statistical Models in S, Wadsworth \& Brooks/Cole.

ICES, 2007. Report of the working group on the biology and assessment of deep-sea fisheries resources (WGDEEP). ICES CM 2007/ACFM:20, 1-486.

ICES. - 2008. Report of the Working Group on the Biology and Assessment of Deep-sea Fisheries Resources (WGDEEP). ICES C.M. 2008/ACOM:14, 1-531.

Ihssen, P.E., H.E. Brooke, J.M. Casselman, J.M. McGlade, N.R. Payne and F.M. Utter. - 1981. Stock identification: materials and methods. Can. J. Fish. Aquat. Sci., 38: 1838-1855.

Iwata, H. and Y. Ukai. - 2002. SHAPE: A computer program package for quantitative evaluation of biological shapes based on elliptic Fourier descriptors. J. Hered., 93: 384-385.

Jacobsen, J.A. and L.P. Hansen. - 2005. Internal and external tags. In: S.X. Cadrin, K.D. Friedland and J.R. Waldman (eds.), Stock identification methods: applications in fisheries science, pp. 
415 -433. Elsevier Academic Press, MA, USA.

Kasapidis, P. and A. Magoulas. - 2008. Development and application of microsatellite markers to address the population structure of the horse mackerel Trachurus trachurus. Fish. Res., 89: 132-135.

Kuhl, F.P. and C.R. Giardina. - 1982. Elliptic Fourier features of closed contour. Comp. Graph. Image Process., 18: 236-258.

Lagler, K.F., J.E. Bardach, R.R. Miller and D.R.M. Passino. - 1977. Ichthyology. John Wiley and Sons, New York.

MacKenzie, K. and P. Abaunza. - 2005. Parasites as biological tags. In: S.X. Cadrin, K.D. Friedland and J.R. Waldman (eds.), Stock identification methods: applications in fisheries science, pp. 211-226. Elsevier Academic Press, MA, USA.

Mauchline, J. and J.D.M. Gordon. - 1984. Occurrence and feeding of the berycomorphid and percomorphid teleost fish in the Rockall Trough. ICES J. Mar. Sci., 41(3): 239-247.

Merrett, N.R., J.D.M. Gordon, M. Stehmann and R.L. Haedrich. 1991. Deep demersal fish assemblage structure in the Porcupine Seabight (eastern North Atlantic) slope sampling by three different trawls compared. J. Mar. Biol. Assoc. U.K., 71: 329-358.

Morales-Nin, B. and D. Sena-Carvalho. - 1996. Age and growth of black scabbard fish (Aphanopus carbo) off Madeira. Fish. Res., 25: $239-251$

Morales-Nin, B., Â. Canha, M. Casas, I. Figueiredo, L.S. Gordo, M. Gordon, E. Gouveia, C.G. Piñeiro, S. Reis, A. Reis and S.C. Swan. - 2002. Intercalibration of age readings of deepwater black scabbardfish, Aphanopus carbo (Lowe, 1839). ICES J. Mar. Sci., 59: 352-364.

Mormede, S.and I.M. Davies. - 2001. Heavy metal concentrations in commercial deep-sea fish from the Rockall Trough. Cont. Shelf Res., 21: 899-916.

Nakamura, I. and N.V. Parin. - 1993. FAO species catalogue. Vol 15. Snake mackerels and cutlassfishes of the world (families Gempylidae and Trichiuridae). An annotated and illustrated catalogue of the snake mackerels, snoeks, escolars, gemfishes, sackfishes, domine, oilfishes, cutlassfishes, scabbardfishes, hairtails and frostfishes known to date. FAO Fish. Synop., 125 (15): $1-136$.

Neves, A., A.R. Vieira, I. Farias, I. Figueiredo, V. Sequeira and L.S. Gordo. - 2009. Reproductive strategies in black scabbardfish, Aphanopus carbo (Teleostei: Trichiuridae). Sci. Mar., 73S2: 19-31.

Pajuelo J.G., J.A. González, J.I. Santana, J.M. Lorenzo, A. GarcíaMederos and V. Tuset. - 2008. Biological parameters of the bathyal fish black scabbardfish (Aphanopus carbo Lowe, 1839) off the Canary Islands, Central-east Atlantic. Fish. Res., 92: 140-147.

Pawson, M.G. and S. Jennings. - 1996. A critique of methods for stock identification in marine capture fisheries. Fish. Res., 25: 203-217.

Perera, C.B. - 2008. Distribution and biology of black scabbardfish (Aphanopus carbo Lowe, 1839) in the Northwest of Africa. Ms thesis, Sciences Faculty, University of Lisbon.

Piotrovskii, A.S. - 1979. On the distribution of the black scabbardfish Aphanopus carbo (family Trichiuridae) in the Indian Ocean. J. Ichthyol., 19: 145-146.

Ponton, D. - 2006. Is geometric morphometrics efficient for comparing otolith shape of different fish species? J. Morphol., 267 750-757.
Quinta, R., L. Gomes and A. Teia dos Santos. - 2004. A mitochondrial DNA PCR-RFLP marker for population studies of the black scabbardfish (Aphanopus carbo). ICES J. Mar. Sci., 61: 864-867.

Reis, S., D. Sena-Carvalho, M. Afonso-Dias and J. Vasconcelos. - 2008. Biological characteristics of Madeira Island black scabbardfish (Aphanopus carbo Lowe, 1839) landings in the past 20 years (1988-2007). Proceedings of XV Simpósio Ibérico de Estudos de Biologia Marinha, 09-13 Setembro, 2008, Funchal, Madeira, Portugal.

Roldan, M.I., J.L. García-Martin, F. Utter and C. Pla. - 1998. Population genetics structure of European hake, Merluccius merluccius. Heredity, 81: 327-334.

Santos, M.J., A. Saraiva, C. Cruz, J.C. Eiras, M. Hermida, C. Ventura and J.P. Soares. - 2009. Use of parasites as biological tags in stock identification of black scabbardfish, Aphanopus carbo Lowe, 1839 (Osteichthyes, Trichiuridae) from Portuguese waters. Sci. Mar., 73S2: 55-62.

Stefanni, S. and H. Knutsen. - 2007. Phylogeography and demography history of the deep-sea fish Aphanopus carbo (Lowe, 1839) in the NE Atlantic: Vicariance followed secondary contact of speciation? Mol. Phylogenet. Evol., 42: 38-46.

Stransky, C., A.G. Murta, J. Schlickeisen and C. Zimmermann. 2008. Otolith shape analysis as a tool for stock separation of horse mackerel (Trachurus trachurus) in the Northeast Atlantic and Mediterranean. Fish. Res., 89: 159-166.

Swain, D.P. and C.J. Foote. - 1999. Stocks and chameleons: the use of phenotypic variation in stock identification. Fish. Res., 43: 113-128.

Swain, D.P., J.A. Hutchings and C.J. Foote. - 2005. Environmental and genetic influences on stock identification characters. In: S.X. Cadrin, K.D. Friedland and J.R. Waldman (eds.), Stock identification methods: applications in fisheries science, $\mathrm{pp}$. 45-85. Elsevier Academic Press, MA, USA.

Swan, S.C., J.D.M. Gordon and T. Shimmield. - 2002. Preliminary investigations on the uses of otolith microchemistry for stock discrimination of the deep-water black scabbardfish (Aphanopus carbo) in the North East Atlantic. J. Northw. Atl. Fish. Sci., 31: 221-231.

Tucker, D.W. - 1950. The biology of Aphanopus carbo Lowe. Rep. Challenger Soc. London, 32: 1-26.

Tuset, V.M., A. Lombarte and C.A. Assis. - 2008. Otolith atlas for the western Mediterranean, north and central eastern Atlantic. Sci. Mar., 72S1: 7-198.

Vieira, A.R., I. Figueiredo, I. Farias, A. Neves, B. Morales-Nin, V. Sequeira, M.R. Martins and L.S. Gordo. - 2009. Age and growth of black scabbardfish (Aphanopus carbo Lowe, 1839) in the southern NE Atlantic. Sci. Mar., 73S2: 33-46.

von Bertalanffy, L. - 1938. A quantitative theory of organic growth (inquiries on growth laws II). Hum. Biol., 10: 181-213.

Ward, R. D. - 2000. Genetics in fisheries management. Hydrobiologia, 420: 191-200.

Zilanov, V.K. and L.I. Shepel. - 1975. A contribution to the ecology of black scabbardfish Aphanopus carbo Lowe in the north Atlantic. J. Ichthyol., 15: 661-663.

Scient. ed.: F. Maynou.

Received December 12, 2008. Accepted October 22, 2009.

Published online December 22, 2009. 